\title{
COMMENTS
}

\section{Allocating Progressive Injury Liability Among Successive Insurance Policies}

\author{
Michael G. Doherty $\dagger$
}

Environmental damage and toxic exposure cases often involve injuries that occur over a number of years, known as "progressive injuries." One recent case, for example, involved the cleanup of an industrial site that had been continuously polluted by oil seepage from the nineteenth century until the 1980 s. $^{2}$ Asbestos exposure cases are another common example; decades of exposure may precede the first manifestation of any symptoms of asbestos-related diseases. ${ }^{3}$

Progressive injuries frequently occur over time periods in which a liable party had insurance coverage under several different insurance policies, often provided by a number of insurance companies. ${ }^{4}$ In most of these cases, it is both scientifically and administratively impossible to allocate to each policy the liability

${ }^{\dagger}$ B.S. 1991, State University of New York at Binghamton; J.D. Candidate 1997, The University of Chicago.

"Progressive injuries" are also referred to as "progressive damages" or "long tail injuries." See, for example, Montrose Chemical Corp v Admiral Insurance, $10 \mathrm{Cal}$ 4th 645, 42 Cal Rptr 2d 324, 328 n 6 (1995) (in bank) ("progressive damages"); Owens-Illinois, Inc $v$ United Insurance Co, 138 NJ 437, 650 A2d 974, 991 (1994) ("long tail injuries").

2 Pittston Co v Allianz Insurance Co, 905 F Supp 1279, 1288 (D NJ 1995).

${ }^{3}$ See, for example, Insurance Co of North America v Forty-Eight Insulations, Inc, 633 F2d 1212, 1214-15 (6th Cir 1980), clarified by 657 F2d 814 (6th Cir 1981) (discussing asbestosis, a disease caused by long-term exposure to asbestos).

- Montrose provides a typical example. Montrose Chemical Company is a defendant in five different environmental and personal injury suits arising out of its manufacture of the pesticide DDT from 1947 until 1982 (DDT's domestic use was banned in 1972). Between 1960 and 1986, seven different insurance companies provided Montrose with liability insurance coverage. $42 \mathrm{Cal}$ Rptr $2 \mathrm{~d}$ at 327. 
for injuries occurring only within its policy period. ${ }^{5}$ When it is impossible to determine the proportion of damage that occurred within each period, the law must allocate damages among the policies.

Courts disagree about the best method for allocating progressive injury liability among insurers. Some courts assign liability to one insurer, chosen by the insured, then permit the selected insurer to sue other insurers for contribution. Other courts allocate the liability among the insurers, with different courts using different allocation formulas. To further complicate the issue, some insureds may self-insure ${ }^{6}$ for part of the time during which the damage occurred. Courts treat such self-insurers inconsistently. Some courts hold that a self-insurer must share the liability with the insurance companies; other courts do not.

As a result of this uncertainty over potential liability, many insurers refuse to write insurance policies covering these types of risks. ${ }^{7}$ This uncertainty also reduces the probability of settlement, further increasing the litigation costs borne by the parties and the judicial system. ${ }^{8}$ Until courts allocate liability more predictably, insurers will litigate many claims and demand higher premiums. ${ }^{9}$

s See, for example, Kenneth S. Abraham, Environmental Liability Insurance Law: An Analysis of Toxic Tort and Hazardous Waste Insurance Coverage Issues 120-23 (Prentice Hall Law \& Bus 1991).

- Self-insurers choose to manage the risks of their activities internally instead of distributing them through the purchase of third-party insurance. They often accomplish this by "setting aside" assets to pay estimated future claims. See generally Robert E. Keeton and Alan I. Widiss, Insurance Law $\$ 1.3(\mathrm{~b})(3)$ at 13-14 (West 1988).

7 Developments in the Law-Toxic Waste Litigation, 99 Harv L Rev 1458, 1575-76 (1986) ("Facing massive awards . . . and fearing further surprises, most insurers have withdrawn from the environmental liability market."); Andrea Gabor and Maria Recio, Pollution Insurance: $U_{p}$ in Smoke?, Bus Week 138G (Feb 18, 1985) (The number of insurers providing environmental insurance dropped from more than a dozen to four in the mid-1980s.); Kenneth S. Abraham, Environmental Liability and the Limits of Insurance, 88 Colum L Rev 942, 944 (1988) (Liability insurance premiums have skyrocketed; for many businesses these policies are unavailable. The "demise" of the liability insurance policy is a symptom of increased legal uncertainty faced by insurance companies.). Of course, the allocation issue is not solely responsible for this uncertainty-toxic tort and environmental law are suffused with uncertainty. See generally id at 942-45, 955-88.

* William R. Hickman and Mary R. DeYoung, Allocation of Environmental Cleanup Liability Between Successive Insurers, $17 \mathrm{~N}$ Ky L Rev 291, $294 \mathrm{n} 6$ (1990) (uncertainty has led to a "litigation bonanza for lawyers"). See also Richard A. Posner, Economic Analysis of Law 555-59 (Little, Brown 4th ed 1992) (As stakes and uncertainty increase, the probability of settlement decreases and litigation costs increase.).

${ }^{9}$ Toxic Waste Litigation, 99 Harv L Rev at 1575-76 (cited in note 7) (suggesting that insurers will resume selling environmental insurance when they can predict liability more accurately); Gabor and Recio, Bus Week at 138G (cited in note 7) (premiums increased by a factor of ten from 1983 to 1985); David B. Hilder, Changes in Liability Insurance Spur Confusion Among Business Clients, Wall St J 33 (Nov 20, 1985). 
The magnitude of the losses in these cases further illustrates the need for courts to choose one method, and apply it consistently, when allocating liability for progressive injuries. Cleanup costs for a polluted site can run into the hundreds of millions of dollars, as can the tort liability faced by a manufacturer of asbestos or other dangerous substances. ${ }^{10}$ Indeed, one insurance rating agency estimated that insurers will pay a total of $\$ 132$ billion for asbestos and environmental claims. ${ }^{11}$ Because of the high stakes involved, each insurer will vigorously fight to ensure that others, including the insured, bear a greater share of the total liability. Thus, some estimate that litigation costs run as high as 75 percent of cleanup costs, at an annual cost of $\$ 500$ million. ${ }^{12}$

This Comment discusses the different methods used by courts to allocate progressive injury liability among insurers. ${ }^{13}$ Section I discusses how a progressive injury claim "triggers" successive insurance policies, thereby making an insurer liable for an insured's liability. Section II discusses the factors that make one allocation method preferable to others. Section III then ex-

so See, for example, Kenneth S. Abraham, Cleaning Up the Environmental Liability Insurance Mess, 27 Valp U L Rev 601, 603-04 (1993) (thirty-million-dollar average cost of remedying hazardous conditions at sites on Superfund "National Priority List"; several hundred million dollars at stake in any given suit); Deborah R. Hensler and Mark A. Peterson, Understanding Mass Personal Injury Litigation: A Socio-Legal Analysis, 59 Brooklyn L Rev 961, 962 n 4 (1993) (In 1991, the total value of all pending asbestos worker injury claims was between eight and fourteen billion dollars.). Trusts established to pay asbestos claimants have been given the majority of the stock of the Manville Corporation and other asbestos producers. Id at $962 \mathrm{n} 5$.

"Chris Roush, Fields of Green-And Disaster Areas, Bus Week 94 (Jan 9, 1995) (estimate of A.M. Best). The New York-based actuarial consulting arm of Towers Perrin has estimated that environmental claims could cost insurers $\$ 1$ trillion over the next fifty years. Chris Roush, The Hurricane Called Superfund, Bus Week 74 (Aug 2, 1993). See also Abraham, Environmental Liability Insurance Law at 1 (cited in note 5) (estimating the combined cost of hazardous waste cleanup and toxic tort claims at several hundred billion dollars).

${ }^{12}$ Owens-Illinois, 650 A2d at 993, citing the testimony of Dr. Joel Hirschhorn before the Subcommittee on Policy Research and Insurance of the House Committee on Banking, Finance, and Urban Affairs, 101st Cong, 2d Sess 3 (Sept 27, 1990); Roush, Bus Week (1993) at 74 (cited in note 11) (of the $\$ 15$ billion spent on Superfund cleanups, 75 percent has gone to legal fees and related costs).

${ }^{13}$ This Comment discusses allocation in the context of both pollution and long-term toxic exposure cases such as asbestos claims. While the situations are not identical, they involve many of the same issues. Commentators have noted the parallels:

The dumping or discharge of the waste is akin to initial exposure to (i.e., inhalation of) asbestos; the leaching of the wastes into the ground and subsurface reservoirs is similar to exposure in residence; and the property damage ultimately discovered is analogous to the manifestation of asbestos-related diseases.

Davis J. Howard, "Continuous Trigger" Liability: Application to Toxic Waste Cases and Impact on the Number of "Occurrences", 22 Tort \& Ins L J 624, 630 (1987). See also Montrose, 42 Cal Rptr 2d at 334 (asserting that property damage and personal injury cases should have the same insurance coverage rules because of similarity of issues). 
amines the different methods used by courts to allocate damages among "triggered" policies, and evaluates them using the factors discussed in Section II. Section IV proposes that courts allocate liability based on the "time-on-the-risk" method. Under this method, an insurer's share of total liability is proportional to the number of years it provided coverage relative to the total number of years of coverage "triggered." This method is predictable, administrable, fundamentally fair, and provides potential insureds with incentives to purchase insurance or rationally self-insure. This method will decrease litigation costs, increase the availability of liability insurance, and reduce further progressive injury damages. ${ }^{14}$

\section{How PROGRESSIVE INJURIES "TRIGGER" SUCCESSIVE INSURANCE POLICIES}

Three basic types of insurance policies cover progressive injury claims. The most frequently used, and litigated, policy is the Comprehensive General Liability ("CGL") policy. ${ }^{15}$ The CGL is a standard form originally drafted in the 1930s by representatives of the insurance industry. ${ }^{16}$ In order to deal with the problem of progressive injuries, the CGL was modified in the 1960s from insuring against "accidents" to insuring against "occurrences."17

In the standard CGL policy, the insurance company agrees to pay "those sums that the insured becomes legally obligated to pay as damages because of 'bodily injury' or 'property damage'

\footnotetext{
${ }^{14}$ This Comment assumes that multiple insurers are liable for a progressive injury claim. It does not discuss pollution exclusion clauses, "owned property exclusions," or other methods used by insurers to attempt to avoid liability for progressive injury claims. Compare Toxic Waste Litigation, 99 Harv L Rev at 1582-83 (cited in note 7) (Judges have "gutted" pollution exclusion clauses.), with Jacquelyn A. Beatty, Exclusions Exclude: Let the Pollution Mean What it Says, 28 Gonzaga L Rev 401, 415 (1993) (pollution exclusions better respected in more recent cases).

This Comment also assumes that there is no factual way to allocate progressive injuries; thus the court must use a method that allocates liability as a matter of law. However, not all progressive injuries are impossible to allocate based on the facts of the situation. See, for example, Uniroyal, Inc v Home Insurance Co, 707 F Supp 1368, 1389, 139394 (E D NY 1988) (using stipulated facts to determine when triggering occurred and to allocate liability). Because courts tend to maximize insurance coverage in individual cases, factual allocation may increase the likelihood that a court will strain to use whatever facts justify the desired result. See text accompanying notes 57-64.

${ }^{15}$ The other two types of policies are the Environmental Impairment Liability ("EIL") policy and the Insurance Services Office ("ISO") policy. The EIL policy covers all claims made during the period of the policy. The ISO policy covers all claims made during a defined period. Because the EIL and ISO policies are infrequently used and even less frequently the subject of allocation litigation, they will not be discussed in this Comment.

${ }^{16}$ See Michael Dore, Insurance Coverage for Toxic Tort Claims: Solving the SelfInsurance Allocation Dilemma, 28 Tort \& Ins L J 823, 823-24 (1993).

${ }^{17}$ Id at 824.
} 
[caused by an occurrence] to which this insurance applies. . . . [The insurance company has] the right and duty to defend any 'suit' seeking those damages." ${ }^{18}$ The policy defines an "occurrence" as "an accident, including continuous or repeated exposure to substantially the same general harmful conditions." Most policies also contain a provision that, "[f]or the purpose of determining the limit of the company's liability, all bodily injury and property damage arising out of continuous or repeated exposure to substantially the same general conditions, shall be considered as arising out of one occurrence."20

Two fundamental problems recur in applying CGL policies to progressive injury claims. First, when is coverage "triggered"? Second, how many "occurrences" are necessary for a progressive injury?

\section{A. Triggering Coverage}

"Trigger" is a label for the events that determine whether an insurance company must respond to a claim against an insured. ${ }^{21}$ Ordinarily, an injury within the effective dates of a policy triggers that policy. ${ }^{22} \mathrm{~A}$ "triggering" question arises, however, when different insurers have insured a company whose products or actions have caused injuries to persons or property at different or uncertain times. ${ }^{23}$ Asbestos exposure and environmental pollution, for example, often occur over more than one policy period. ${ }^{24}$ Theoretically, damages that occur in different policy periods are divisible. In practice, however, the harms are cumulative with, and thus indivisible from, harms suffered in earlier periods. ${ }^{25}$ Which policies have been triggered?

${ }^{17}$ Keeton and Widiss, Insurance Law, appendix $J(1)$ at 1243 (cited in note 6).

${ }^{14}$ Id at 1251.

Hickman and DeYoung, $17 \mathrm{~N}$ Ky L Rev at $293 \mathrm{n} 4$ (cited in note 8). See also Insurance Co of North America v Forty-Eight Insulations, Inc, 633 F2d 1212, 1227-28 (6th Cir 1980 ), clarified by $657 \mathrm{~F} 2 \mathrm{~d} 814$ (6th Cir 1981) (presenting the basically identical language of all the different insurance policies in question); Keene Corp $v$ Insurance Co of North America, 667 F2d 1034, 1053-57 (DC Cir 1981) (same).

${ }^{21}$ Abraham, 88 Colum L Rev at 970-71 (cited in note 7); Montrose Chemical Corp v Admiral Insurance Co, $10 \mathrm{Cal} 4$ th 645, 42 Cal Rptr 2d 324, 326-27 n 2 (1995) (in bank).

2 Uniroyal, Inc $v$ Home Insurance Co, 707 F Supp 1368, 1387 (E D NY 1988).

$\approx$ Id.

4 Abraham, Environmental Liability Insurance Law at 98-102 (cited in note 5).

${ }^{2}$ Id at 100-02. For an example of conflicting judicial views about when damages actually occur, compare Eagle-Picher Industries, Inc v Liberty Mutual Insurance Co, 682 F2d 12, 18 (1st Cir 1982) (Asbestos inhalations do not inevitably result in injury.), with Owens-Illinois, Inc v United Insurance Co, 138 NJ 437, 650 A2d 974, 982-83 (1994) (Some injury occurs upon inhalation of asbestos.). 
In order to answer this question, courts have developed four different theories for fixing the date of injury when the time of the actual injury cannot be ascertained. ${ }^{26}$ The "exposure" theory fixes the date of injury as the date on which the injury-producing agent first contacted the body or the date on which pollution began. ${ }^{27}$ The "manifestation" theory holds that the compensable injury does not occur until it manifests itself in the form of a diagnosable disease or ascertainable property damage. ${ }^{28}$ The "continuous trigger" theory, also known as the "triple trigger" theory, provides that the injury occurs continuously from exposure until manifestation. ${ }^{29}$ Finally, the "injury-in-fact" theory allows the finder of fact to place the injury at any point in time that the effects of exposure resulted in an actual and compensable injury. ${ }^{30}$ Injury-in-fact can occur at exposure, at manifestation, or at any time in between. ${ }^{31}$ In practice, the inability to pin down, or even to approximate, when the injury-in-fact occurred often causes this test to yield the same result as the "continuous trigger" test. ${ }^{32}$

In order to be consistent with the majority of courts that have considered the issue, this Comment will assume the use of a continuous trigger, or a similarly applied injury-in-fact trigger, to answer the triggering question. ${ }^{33}$

${ }^{25}$ For a state-by-state breakdown of "trigger law," see generally Martin J. McMahon, Event Triggering Liability Insurance Coverage as Occurring Within Period of Time Covered by Liability Insurance Policy Where Injury or Damage is Delayed-Modern Cases, 14 ALR5th 695 (1993).

${ }^{27}$ See, for example, Forty-Eight Insulations, 633 F2d at 1223; Cole $v$ Celotex Corp, 599 S2d 1058, 1076 (La 1992); Commercial Union Insurance Co v Sepco Corp, 765 F2d 1543, 1546 (11th Cir 1985).

${ }^{2}$ See, for example, Eagle-Picher, 682 F2d at 24-25; Mraz $v$ Canadian Universal Insurance Co, Ltd, 804 F2d 1325, 1328 (4th Cir 1986).

${ }^{2}$ See, for example, Keene Corp v Insurance Co of North America, 667 F2d 1034, 104247 (DC Cir 1981); Lac D'Amiante du Quebec, Ltee v American Home Assurance Co, $613 \mathrm{~F}$ Supp 1549, 1560-61 (D NJ 1985); Montrose, 42 Cal Rptr 2d at 347.

${ }^{30}$ See, for example, American Home Products Corp v Liberty Mutual Insurance Co, 748 F2d 760, 764-66 (2d Cir 1984); Abex Corp v Maryland Casualty Co, 790 F2d 119, 12728 (DC Cir 1986).

${ }^{31}$ Uniroyal, Inc $v$ Home Insurance Co, 707 F Supp 1368, 1388 (E D NY 1988).

${ }^{32}$ See, for example, Sentinel Insurance Co $v$ First Insurance Co of Hawaii, Ltd, 76 Hawaii 277, 875 P2d 894, 917-18 (1994) (adopting injury-in-fact trigger but stating that the injury-in-fact can occur over a continuous period, giving rise to the use of a continuous trigger); United States Gypsum Co v Admiral Insurance Co, 268 Ill App 3d 598, 643 NE2d 1226, 1255 (1994) ("Conceptually, the injury in fact trigger and the continuous trigger are on the same continuum and are complementary, rather than mutually exclusive.").

${ }^{33}$ Other commentators have used this method when discussing the allocation issue. See Hickman and DeYoung, $17 \mathrm{~N}$ Ky L Rev at 295-96, 300 (cited in note 8). See also Montrose, 42 Cal Rptr $2 \mathrm{~d}$ at 342, 348 n 22 (observing that most courts deciding CGL cases use the "continuous trigger" method). 


\section{B. The Number of Occurrences}

Courts use "the number of occurrences" as a factor to determine the amount of liability an insured must absorb before being indemnified. ${ }^{34}$ Most insurance policies limit the total amount that may be paid per occurrence by providing that the insured must absorb a specified deductible for each occurrence before the insurer becomes liable and by limiting the total amount of coverage per occurrence. ${ }^{35}$

The standard CGL language does not equate the "occurrence" with the injury; instead, it defines the injury as resulting from the occurrence. ${ }^{36}$ As noted by the Sixth Circuit:

The vast majority of courts . . . have concluded that although injury must be suffered before an insured can be held liable, the number of occurrences for purposes of applying coverage limitations is determined by referring to the cause or causes of the damage and not to the number of injuries or claims. The number and timing of injuries is relevant in addressing the distinct question of the policy period to which each injury will be assigned. ${ }^{37}$

This Comment will assume that there is one occurrence for the purpose of allocating insurance liability. The CGL language, when applied to the typical progressive injury fact pattern, supports this assumption. "For the purpose of determining the limit of the company's liability, all bodily injury and property damage arising out of continuous or repeated exposure to substantially the same general conditions, shall be considered as arising out of one occurrence." ${ }^{38}$

"See Uniroyal, 707 F Supp at 1379-80. The use of "indemnify" is somewhat inexact. The insurer does not pay or indemnify the insured; it pays an injured party "on behalf of the insured." However, "indemnify" is the term customarily used by both courts and commentators. Hickman and DeYoung, $17 \mathrm{~N} \mathrm{Ky} \mathrm{L} \mathrm{Rev} \mathrm{at} 312 \mathrm{n} 66$ (cited in note 8).

* Toxic Waste Litigation, 99 Harv L Rev at 1582 (cited in note 7).

Uniroyal, 707 F Supp at 1380.

${ }^{*}$ Michigan Chemical Corp v American Home Assurance Co, 728 F2d 374, 379 (6th Cir 1984) (citations omitted).

3* Hickman and DeYoung, 17 N Ky L Rev at 293 n 4 (cited in note 8) (emphasis added). The majority of courts focus on the "cause" of the injury when determining the number of occurrences. Id at 297. See also, for example, Uniroyal, $707 \mathrm{~F}$ Supp at 1383 (finding production of Agent Orange was one occurrence because it encompassed a series of continuous and interrelated actions). But see Toxic Waste Litigation, $99 \mathrm{Harv} \mathrm{L}$ Rev at 1582 (cifsd in note 7) (A court attempting to maximize total insurance coverage will find th. ne multiple occurrences occurred if policy has low deductible and low total limits per oc:urrence.). 


\section{THE QUALITIES OF THE OPTIMAL ALlOCATION METHOD}

This Section argues that the optimal allocation method should minimize the total costs that progressive injuries impose on society and increase the availability of liability insurance. Contrary to the inclination of some courts, however, the allocation method should not attempt to maximize total insurance coverage in individual allocation cases.

\section{A. Minimizing Total Costs}

The overriding goal of any method for allocating liability should be to minimize the total costs that progressive injuries impose on society. Progressive injury cases impose four types of costs: (1) avoidance costs - the costs of preventing harm by, for example, using expensive alternative materials or processes; (2) abatement costs-the costs of fixing the harm that has occurred by, for example, cleaning up a hazardous waste site; (3) compensation costs - the costs of making whole those who have been harmed by, for example, compensating victims who have inhaled asbestos and, thereby, developed asbestosis; and (4) transaction costs - the costs of allocating avoidance, abatement, and compensation costs among "responsible parties," insureds, victims, government, insurers, and third parties. ${ }^{39}$ Efficiency requires that any solution attempt to minimize all four costs. ${ }^{40}$

While fairness is another concern, cost-based efficiency analysis considers fairness. Of course, making a polluter pay for the costs of pollution forces the polluter to internalize those costs, thereby giving it a strong incentive to minimize them. But fairness also requires consistent application of rules and predictable results. Simplistic application of slogans like "make the polluter pay" can yield wildly unpredictable results. ${ }^{41}$

${ }^{39}$ See Toxic Waste Litigation, 99 Harv L Rev at 1482 (cited in note 7). The Comprehensive Environmental Response, Compensation, and Liability Act of 1980 ("CERCLA"), Pub L No 96-510, 94 Stat 2767, codified at 42 USC $\$ \$ 9601$ et seq (1994), also known as the "Superfund" law, defines "responsible parties" as including past or present owners or operators of a cleanup site, transporters of hazardous material to a site, and any party who generated material deposited at a site. 42 USC $\$$ 9607(a).

${ }^{40}$ See Toxic Waste Litigation, 99 Harv L Rev at 1477-80 (cited in note 7).

"Results are especially unpredictable in cases where the plaintiff seeks to make a polluter retroactively liable for the full cost of cleanup even though the polluter only has contributed a small amount to the total pollution. Under CERCLA, liability of "responsible parties" for environmental damages is "strict, retroactive, and (except when the harm caused by different parties is divisible) joint and several," with extremely limited defenses to liability. Abraham, 27 Valp U L Rev at 603 (cited in note 10) (footnotes omitted). For a definition of "responsible parties," see note 39. 
By the time allocation cases reach the courts, progressive injuries have already occurred. Thus, the avoidance, abatement, and compensation costs discussed above are "sunk" costs that are unaffected by the allocation decision, although the allocation decision determines the distribution of these costs among the parties. ${ }^{42}$ It follows that, since the allocation rule cannot alter sunk costs, it should focus instead on minimizing transaction costs.

The transaction costs of allocating avoidance, abatement, and compensation are substantial. Environmental litigation costs are estimated at as much as $\$ 500$ million per year. ${ }^{43}$ Indeed, for each dollar spent on the indemnification of asbestos claims, more than two dollars are expended on litigation and other transaction costs. ${ }^{44}$ These transaction costs are wasted costs; they only allocate environmental damages but do not control them. Of course, insurers will factor these costs into their premium calculations and further increase the price of insurance. ${ }^{45}$

\section{B. The Availability Of Insurance}

In addition to minimizing transaction costs, the choice of allocation method can also indirectly affect the availability of liability insurance. This, in turn, indirectly affects the costs that progressive injuries impose on society. A healthy liability insurance market helps to deter progressive injuries, achieve corrective justice, and compensate victims. ${ }^{46}$ High levels of uncertainty, reflected in high premiums and the unwillingness to write insurance policies, have helped cause the "demise of the environmental liability insurance market." ${ }^{\prime 77}$ If this uncertainty is not reduced, and if litigation costs, in large part borne by insurance companies and thus reflected in premiums, are not decreased, insurance will not be available to help reduce total progressive injury costs. ${ }^{48}$

Insurance helps to reduce the costs of progressive injuries in three ways. First, it spreads risk from those who are risk averse to other more willing and more efficient risk bearers. ${ }^{49}$ As noted by the New Jersey Supreme Court, because insurers are more efficient risk bearers, any allocation method should, "at a mini-

\footnotetext{
12 Posner, Economic Analysis of Law at 5-10 (cited in note 8).

4 See text accompanying notes 10-12.

"Hensler and Peterson, 59 Brooklyn L Rev at 962 n 4 (cited in note 10).

* See text accompanying notes 60-63.

${ }^{43}$ Abraham, 88 Colum L Rev at 944-45 (cited in note 7).

17 Id at 944.

See Toxic Waste Litigation, 99 Harv L Rev at 1575-76 (cited in note 7).

See Abraham, 88 Colum L Rev at 945-46 (cited in note 7).
} 
mum, not provide disincentives to . . . acquire insurance. ${ }^{150} \mathrm{Sec}$ ond, insurance promotes safety. By tailoring premiums to the level of risk incurred, insurance forces insured companies to internalize the costs of their activities. ${ }^{51}$ Insurance also helps those companies assess and manage the risks involved in their activities. $^{52}$

Finally, insurance also reduces the costs of progressive injuries by decreasing the risk of bankruptcy. If insurance is unavailable, a company is more likely to go bankrupt due to the threat of tremendous liability. ${ }^{53}$ Companies can discount the value of possible claims against them by the probability of avoiding many of these claims through bankruptcy. ${ }^{54}$ This, in turn, allows companies to avoid internalizing the costs of these activities and leads to larger progressive injury costs. ${ }^{55} \mathrm{As}$ an alternative to courting bankruptcy by operating without insurance, some companies will simply discontinue their operations. ${ }^{56}$

\section{Rejecting Coverage Maximization}

Many courts use a "coverage maximization" rationale to allocate liability for progressive injuries. ${ }^{57}$ Too often, courts choose

so Owens-Illinois, Inc v United Insurance Co, $138 \mathrm{NJ} 437,950$ A2d 974, 992 (1994).

${ }^{51}$ Abraham, 88 Colum L Rev at 954-55 (cited in note 7).

${ }^{52}$ Insurers set premiums after performing detailed studies of an insured's practices and comparing these practices with those of other companies participating in similar activities. Insurers then inform insureds of the risks they face and advise them of precautions that can minimize the expected future damages caused by these activities. Id.

${ }^{53}$ See Toxic Waste Litigation, 99 Harv L Rev at 1585-86 (cited in note 7) (Risking bankruptcy instead of insuring is increasingly the route chosen by companies.). See also Kaighn Smith, Jr., Comment, Beyond the Equity Power of Bankruptcy Courts: Toxic Tort Liabilities in Chapter 11 Cases, 38 Me L Rev 391, 391-92 (1986) (discussing four companies that declared bankruptcy because of mounting asbestos-related claims). See generally Wilbur N. Moulton, et al, Business Failure Pathways: Environmental Stress and Organizational Response, J Mgmt, 1996 WL 10589404 (discussing reasons for firm bankruptcies).

${ }^{54}$ A full discussion of the treatment of progressive injury claims in bankruptcy is beyond the scope of this Comment. For a more thorough discussion, see Toxic Waste Litigation, 99 Harv L Rev at 1585-1601 (cited in note 7).

ss Id at 1592, 1597-98.

${ }^{56}$ Abraham, 88 Colum $L$ Rev at 948 (cited in note 7) (noting that "liability insurance is as important to many enterprises as electricity").

${ }^{37}$ See American Home Products Corp v Liberty Mutual Insurance Co, 565 F Supp 1485,1510 (S D NY 1983), affirmed as modified, 748 F2d 760 (2d Cir 1984) (stating that coverage maximization is the driving rationale behind most allocation decisions and disapproving of this tendency); Owens-Illinois, Inc $v$ United Insurance Co, $138 \mathrm{NJ} 437,650$ A2d 974, 981 (agreeing with American Home Products); Lac D'Amiante du Quebec, Ltee $v$ American Home Assurance, 613 F Supp 1549, 1551 (D NJ 1985) (stating that different outcomes are result of courts' desire to maximize coverage and calling this result "understandable"). See also Hickman and DeYoung, $17 \mathrm{~N} \mathrm{Ky} \mathrm{L} \mathrm{Rev} \mathrm{at} 315$ (cited in note 8) (stating that the "proliferation of different theories" of coverage allocation is best ex- 
this method because it allocates the most liability to insurers and the least to the insured in a particular case ${ }^{58}$ There are several reasons, however, why courts should reject this rationale for allocating liability.

In the long term, coverage maximization produces both inefficient and unfair results. As noted by the court in American Home Products Corp v Liberty Mutual Insurance Co, "broader coverage has a price that must ultimately be paid." 59 Insurers calculate premiums to equal the sum of total expected liability within the policy period, plus a reserve in case they underestimate future losses, plus expenses and expected profit. ${ }^{60}$ Thus, if insurance companies anticipate an increase in future liabilities resulting from courts' attempts to maximize coverage in individual cases, they will raise their premiums to reflect the expected increased liability. ${ }^{61}$ In addition, if insurers cannot accurately predict their future liabilities because courts allocate liability on a case-by-case basis, premiums will further increase to reflect this uncertainty. ${ }^{62}$ The uncertainty flowing from coverage maximization increases the range of possible outcomes of the case because insurers cannot know when determining premiums which rule the court will apply. Such uncertainty also decreases the likelihood of settlement, thereby increasing the costs of litigation. ${ }^{63}$

Finally, coverage maximization reduces the incentives for insureds to discover and limit progressive injury damage. If insurers pay more of the insured's liability, the insured must pay less and consequently will be less concerned about limiting injury. ${ }^{64}$ Of course, future premiums will reflect increased liability, but

plained as "judicially adopted public policy of maximizing coverage").

* See, for example, Keene Corp $v$ Insurance Co of North America, 667 F2d 1034, 1048

(DC Cir 1981) ("[Indispensible initial premise" of decision is that the insured has the "right to be free of all liability.").

565 F Supp 1485, 1511 (S D NY 1983), affirmed as modified, 748 F2d 760 (2d Cir 1984).

${ }^{\infty}$ See generally Keeton and Widiss, Insurance Law $\S 1.3(\mathrm{~b})$ at 11-13 (cited in note 6). See also American Home Products, 565 F Supp at 1506-08 (providing example of how insurance rates are calculated and negotiated between insured and insurer).

${ }^{\text {"I }}$ American Home Products, 565 F Supp at 1511 (noting that insurance premiums rise in anticipation of judicially-created liabilities).

"2 See Abraham, 88 Colum L Rev at 944 (cited in note 7) ("The demise of the environmental liability insurance market is a symptom of . . . high levels of legal uncertainty."). See generally id at 944-56. This increased legal uncertainty adversely affects self-insurers as well as insurance companies. Id at 948-49.

* Hickman and DeYoung, $17 \mathrm{~N} \mathrm{Ky} \mathrm{L} \mathrm{Rev} \mathrm{at} 312$ (cited in note 8). See also Posner, Economic Analysis of Law at 555-59 (cited in note 8) (the greater the uncertainty and gap between possible outcomes, the less the likelihood of settlement).

A Hickman and DeYoung, $17 \mathrm{~N}$ Ky L Rev at 303 (cited in note 8). 
this threatened increase may not worry an insured that knows its hazardous activity will decrease or that plans to self-insure in the future.

Courts attempt to justify coverage maximization in two ways. First, they appeal to the doctrine of "reasonable expectations." According to this doctrine, an insurer is liable for the coverage that an insured would reasonably expect to be provided by the policy in question. ${ }^{65}$ However, the doctrine of reasonable expectations applies only when the expectations to be enforced are strongly demonstrated, and the policy in question is an adhesion contract. ${ }^{66}$ As Judge Wald noted, insureds cannot have reasonable expectations of receiving coverage for which they have not paid. ${ }^{67}$ Furthermore, it is questionable whether assessing reasonable expectations is even possible when both scientific knowledge and the legal rules affecting liability, factors which combine to determine the size and the allocation of liability, change frequently.$^{68}$ Finally, an insured's reasonable expectations must also be a function of the legal rule applied by courts; if courts consistently apply a rule that does not maximize coverage, an insured can have no reasonable expectation of coverage maximization.

Courts also attempt to justify coverage maximization by construing any ambiguities in a policy against the insurer. There are three reasons why this construction does not justify coverage maximization. First, this doctrine does not apply to powerful and sophisticated insureds who can quite ably protect themselves against contracts of adhesion. ${ }^{69}$ Second, the language in the insurance policy does not ambiguously suggest several allowable allocation methods, one of which is most favorable to the insured. Indeed, the policy does not address the allocation issue at all because the allocation issue arises outside the scope of the insurance contract, designed to bind one insured to one insurer. ${ }^{70} \mathrm{Fi}$ nally, even when the insured is a small- to medium-sized company that may not be able fully to protect itself against contracts of adhesion, applying this doctrine to maximize coverage in indi-

* See generally Keeton and Widiss, Insurance Law $\S \S 6.1(a), 6.3$ at 614-16, 627-46 (cited in note 6).

* Compare American Home Products, 565 F Supp at 1511 (reasonable expectations inapplicable in allocation cases), with Keene, 667 F2d at 1041-42 (relying on reasonable expectations doctrine to maximize coverage).

${ }^{\circ}$ Keene, 667 F2d at 1058 (Wald concurring in part).

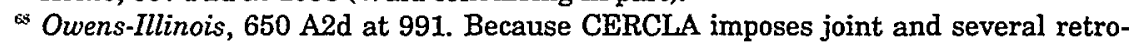
active liability on polluters, see notes 39 and 41 , the court questioned how an insured could develop any expectations about the allocation of this liability.

${ }^{9}$ See, for example, Pittston Co v Allianz Insurance Co, 905 F Supp 1279, 1320 (D NJ 1995).

${ }^{70}$ Owens-Illinois, 650 A2d at 989 . See also note 73. 
vidual cases will, in the long term, increase insurance premiums and cause the adverse effects described above. ${ }^{71}$

\section{ALLOCATION METHODS USED BY COURTS}

As discussed above, it is often impossible for courts to determine the amount of progressive injury damage that occurred within a given policy period. ${ }^{72}$ In addition, the standard CGL policy is of little assistance because it does not address the allocation of progressive injury liability among successive insurance policies. ${ }^{73}$ As a result, courts have used a number of different methods in attempting to fill this gap. This Section discusses and critiques each of those methods.

\section{A. The "Joint and Several Liability" Method}

Several courts have held that each "triggered" insurer is jointly and severally liable for the insured's entire indemnity and defense costs. The seminal case embracing this approach is Keene Corp $v$ Insurance Co of North America, in which the D.C. Circuit held that each triggered insurer was jointly and severally liable for the indemnity and defense costs resulting from a rash of asbestos-related lawsuits against the insured, including periods during which Keene had self-insured. ${ }^{74}$ The court allowed the insured to select one triggered policy that would be responsible for the full amount, subject to the policy's deductible and coverage limits; a triggered policy could escape liability only if the insurer could prove that none of the injuries at issue could have occurred during its coverage period. ${ }^{75}$ After liability was assessed, the selected insurance carrier could sue (or negotiate with) other triggered insurers for contribution.

The reasoning behind the joint and several liability method, as illustrated by Keene, begins with the premise that the insured purchased from its insurers the right to be free from all liability.

"See text accompanying notes 57-64.

${ }^{72}$ See text accompanying notes $4-5,22-25$.

${ }^{23}$ See, for example, Keene Corp $v$ Insurance Co of North America, 667 F2d 1034, 1041 (DC Cir 1981) ("Unfortunately, the insurance companies failed to develop policy language that would directly address the full complexity entailed by asbestos-related diseases.").

" 667 F2d 1034, 1049-50 (DC Cir 1981) (Bazelon opinion). For other cases using this method, see Monsanto Co $v$ CE Health Compensation and Liability Insurance Co, $652 \mathrm{~A} 2 \mathrm{~d}$ 30, 35 n 6 (Del 1994) (calling joint and several liability the "majority rule" and citing cases).

${ }^{73}$ Keene, 667 F2d at 1052. Normally the burden to prove coverage is on the insured, but the court reversed this presumption and noted that "[r]eversal of the ordinary burden of proof will be more equitable for all parties and will prevent unnecessary litigation." Id at $1052 \mathrm{n} 42$. 
It follows that, if the insured's damages are allocated among different policies, each policy fails in its primary function of relieving the insured of its liability by denying the coverage purchased by the insured. ${ }^{76}$ Therefore, the argument concludes, the insured ought to be permitted to select one insurer to indemnify it up to the limits of the policy selected. Presumably, the insured will pick the policy that minimizes its out-of-pocket expenses.

Keene's reasoning relies on a faulty premise to reach an inefficient result. Indeed, as the New Jersey Supreme Court observed, shoehorning all damages into one policy period is "intuitively suspect" and inconsistent with the development of toxic tort jurisprudence. ${ }^{77}$ An insured purchases an insurance policy to indemnify it against injuries occurring within the policy period, not injuries occurring outside that period. Because an insured can select any one of the triggered policies, the Keene method implicitly admits that some damages occurred outside the selected policy period. However, in Keene, the court nonetheless pretended that all the damages occurred within the coverage period of the selected policy.

The Keene method also repudiates its own reasoning by allowing the selected insurer to seek contribution from other triggered insurers. After all, if the reasoning behind joint and several liability is to force the insurer to provide the coverage paid for, it does not follow that the selected insurer should be allowed to force other insurers to help provide that coverage. ${ }^{78}$ Indeed, under this reasoning, an insurer should be liable for damage occurring within its policy period, and nothing more.

Keene's faulty reasoning might be excusable if it yielded efficient results, but it does not. Under Keene, the selected insurer can sue or negotiate with the other triggered insurers for contribution. However, Keene suggests no method that allocates damages among the insurers; it proposes only to allocate liability by using facts or "other insurance" clauses. ${ }^{79}$ But this approach overlooks the fact that, if courts could allocate liability based on the facts of the case, there would be no need for a legal ruleeach insurer would be liable for the damages that actually occurred under its policy. As discussed above, however, progressive

${ }^{76}$ Id at 1047-49.

${ }^{7}$ Owens-Illinois, Inc $v$ United Insurance Co, 138 NJ 437, 650 A2d 974, 989 (1994).

${ }^{78}$ Id at 987.

${ }^{79}$ Keene, $667 \mathrm{~F} 2 \mathrm{~d}$ at 1051-52. Keene suggested only that damages be allocated using the facts developed in the underlying tort litigation or the "other insurance" clauses in the triggered policies. Id at 1050-52. For a discussion of the fact-based method and its shortcomings, see note 14. For a discussion of why "other insurance" clauses do not solve the allocation dilemma, see Section III.D. 
injury claims are problematic precisely because courts cannot determine exactly when actual injuries occurred. ${ }^{80}$

Thus, Keene does not solve the allocation problem; it merely postpones it. Indeed, the joint and several method divides the case into two separate suits: in the first suit, the insured selects and sues one of the triggered insurers; in the second suit, the selected insurer then sues other triggered insurers for contribution. ${ }^{81}$ Litigation costs do not decrease, courts lack a method for allocating liability, and insurers still need to factor the costs of uncertain liability into their premiums.

The Keene method could avoid the costs of contribution suits by prohibiting contribution, but wasteful litigation costs would still remain: an insurer that provides insurance for one year could be saddled with liability for injuries occurring over a decades-long period. A selected insurer faced with the prospect of paying a mammoth amount of damages with no hope of contribution would have a strong incentive to drag out the litigation, hoping to extract a more favorable settlement. ${ }^{82}$ Moreover, because the insurer has the duty to defend as well as indemnify the insured ${ }^{83}$ it would have an incentive to expend socially wasteful litigation costs in an effort to allocate a greater share of the damage costs to the other parties. ${ }^{84}$

In addition, under the Keene method, insurers need to factor into their premiums the possibility of compensating for injuries outside the policy period. Thus, if all courts adopted the Keene method, premiums would naturally rise and exacerbate the existing insurance crisis. Furthermore, insurers, knowing that an insured will likely select the policy providing the most coverage, would be discouraged from writing generous (high-coverage) poli-

See text accompanying notes 4-5 and 22-25.

"Keene, 667 F2d at 1051. See also Hickman and DeYoung, $17 \mathrm{~N} \mathrm{Ky} \mathrm{L} \mathrm{Rev} \mathrm{at} 315$ (cited in note 8) ("II]t has been judicial inability or refusal to squarely face the allocation problem, compounded by attempts to avoid the problem by pretending to impose joint and several liability, which has led to the substantial confusion presently surrounding the allocation question.").

${ }^{2}$ Posner, Economic Analysis of Law at 555-59 (cited in note 8) (demonstrating that increased litigation stakes increase litigation expenditures and decrease probability of settlement).

$\therefore$ See Section IV.

Indeed, the selected insurer will continue to litigate as long as the costs of litigation are less than the amount of damages allocated away from the insurer and to the other parties. See, for example, Alan O. Sykes, Judicial Limitations on the Discretion of Liability Insurers to Settle or Litigate: An Economic Critique, 72 Tex L Rev 1345, 1345-46 (1994) (demonstrating that insurer has incentive to litigate if it can allocate more losses to other parties than it spends litigating). Presumably, in the course of defending the insured, the insurer will first dispute the insured's liability. It may then dispute the amount owed the insured for indemnification. 
cies because the increased probability of selection would increase the likelihood of paying for injuries occurring outside the policy period.

The Keene method is also unfair; it refuses to hold the insured liable for periods of self-insurance. An insurer that provided coverage for one year might have to pay for all injuries occurring during a nineteen-year period, even if the insured did not have insurance for the other eighteen years. ${ }^{85}$ Such a result ignores the reality of the insurance market. Companies decide to self-insure when they conclude that self-insurance costs less than third-party insurance. ${ }^{86}$ The court in Keene reasoned that, by contracting with the insured, the insurance companies agreed to relieve the insured of all liability, even during periods of selfinsurance. ${ }^{87}$ Despite this assertion, self-insurers do expect to be liable for injuries caused during the self-insured periods. Indeed, they often hire management companies to determine the amount of reserves that should be set aside for claims and to manage the self-insurance effort. ${ }^{88}$

Furthermore, relieving a self-insurer of liability for injuries occurring during the self-insured periods allows the self-insurer to externalize costs. A company that pays insurance premiums will be encouraged to take precautions against injuries, because insurers tailor premiums to reflect expected losses. Similarly, a self-insurer will take precautions knowing that it will pay directly for the costs of injuries. By forcing a third-party insurer to

${ }^{65}$ Owens-Illinois, 650 A2d at 992-93, citing Insurance Co of North America v FortyEight Insulations, Inc, 633 F2d 1212, 1225 (6th Cir 1980), clarified by 657 F2d 814 (6th Cir 1981). See also Keene, $667 \mathrm{~F} 2 \mathrm{~d}$ at 1058 (Wald concurring in part) (advocating the time-on-the-risk method with allocation to insured for periods of self-insurance).

${ }^{86}$ See, for example, American Home Products, 565 F Supp at 1507-08 (describing how American Home Products' insurance manager decided that self-insurance was the most economically attractive method). See also Abraham, 88 Colum L Rev at 948 (cited in note 7) (discussing how a company compares costs of third-party insurance with self-insurance and selects the alternative that melds best with its capital structure).

${ }^{87}$ Keene, 667 F2d at 1049.

${ }^{6}$ See Owens-Illinois, 650 A2d at 976-77 (describing Owens-Illinois's self-insurance effort, which included hiring a management company and forming a wholly-owned captive insurance company). As Judge Wald observed in Keene:

I just do not understand why an asbestos manufacturer, which has consciously decided not to insure itself during particular years of the exposure-manifestation period, should have a reasonable expectation that it would be exempt from any liability for injuries that were occurring during the uninsured period. ... [A]ll those who voluntarily assumed risk during the period when the diseases progressed must share the responsibility for the judgment and this includes self-insurers [or else] a manufacturing company that purchased insurance intermittently during the risk period would be as secure as those prudent companies that continually purchased insurance.

Keene, 667 F2d at 1058 (Wald concurring in part). 
pay for injuries occurring during the self-insured period, the Keene method gives a self-insurer no incentive to internalize the costs of its actions and take precautions against causing progressive injuries during self-insured periods. ${ }^{39}$

\section{B. The "Stacking Coverage" Method}

"Stacking" permits the insured to aggregate the coverage limits of triggered policies, thereby creating a larger pool out of which the insured may be compensated. ${ }^{90}$ Also known as "horizontal exhaustion," this method allows the insured to exhaust the coverage limits of all the policies up to the level of its loss. ${ }^{91}$ For example, a two-year progressive injury that triggered successive insurance policies $A$ (with a coverage limit of $\$ 1$ million) and B (with a coverage limit of $\$ 2$ million) would, if stacked, allow the insured to recover up to $\$ 3$ million for the injury. Stacking allows the insured to select any triggered policy. When the insured reaches the limits of the first policy selected, it selects another triggered policy and continues until it either exhausts all the policies or it is fully indemnified. ${ }^{92}$

One court has suggested that a selected insurer might be permitted to sue other triggered insurers for contribution when the injury does not exhaust the coverage limits of all the triggered policies..$^{93}$ If the progressive injury in the above example resulted in damages of $\$ 1.5$ million, the insured would presumably select $B$, the larger policy. Policy B's limits would not be reached, but perhaps insurer $B$ could then sue $A$ for contribution.

Because courts suggest that the insurers selected to indemnify the insured can sue other triggered insurers for contribution,

\footnotetext{
${ }^{69}$ See text accompanying notes 46-56.

${ }^{5}$ Abraham, Environmental Liability Insurance Law at 123-26 (cited in note 5). Some controversy exists as to the frequency of this method's use. Some commentators suggest it is used infrequently, see Cole v Celotex Corp, 599 S2d 1058, 1077 n 56 (La 1992), citing Neil H. Selman, Exposure to a Manifest Injustice: the Argument Against Horizontal Stacking in Latent Injury and Damage Cases, 5 Mealey's Litigation Reports: Insurance 16, 25 (1990) (noting that only Louisiana continues to use "stacking"). See also J.H. France Refractories Co v Allstate Igsurance Co, $534 \mathrm{~Pa} 29,626$ A2d 502, 509 (1993) ("When the policy limits of a given insurer are exhausted, [the insured] is entitled to seek indemnification from any of the remaining insurers which was on the risk during the development of the disease.").

${ }^{91}$ Uniroyal, Inc $v$ Home Insurance Co, 707 F Supp 1368, 1392 (E D NY 1988).

${ }_{52}$ J.H. France, 626 A2d at 508-09; Cole, 599 S2d at 1077-80. It is unclear whether the insured would have to meet the deductible, if any, for each selected policy. Uniroyal suggests, without deciding, that all deductibles must be met. 707 F Supp at 1391. Cole and J.H. France are silent on this issue. However, the tendency of courts to maximize coverage in individual cases, see notes 57-58 and accompanying text, suggests that insureds would need to meet but one deductible.

${ }^{s}$ See J.H. France, 626 A2d at 509, citing Keene, 667 F2d at 1050.
} 
the stacking method, like the joint and several liability method, threatens to be little more than a method to split the case into two suits. A selected insurer will sue the other insurers for contribution, and the courts, still without a rule, will then face the familiar allocation question. ${ }^{94}$

Even if courts prohibit contribution, stacking suffers the same problems that make the Keene method unacceptable. As discussed above,$^{95}$ an insurer, if forced to pay for injuries largely sustained outside the policy period, will increase premiums and engage in wasteful litigation. More ominously, while Keene limits total recovery to the limits of one policy, the stacking method potentially reaches the limits of all the triggered policies. This magnifies the problems with coverage maximization, inherent in the joint and several liability method. Finally, like Keene, stacking forces insurers to provide insurance coverage during periods of self-insurance. As discussed above, such an approach ignores the reality of the insurance market, increases premiums, and reduces the availability of insurance. ${ }^{96}$

\section{The "Coverage Provided" Method}

In Owens-Illinois, Inc $v$ United Insurance Co, the New Jersey Supreme Court recently allocated liability for asbestos-related claims based on the "coverage provided" by each insurer. ${ }^{97}$ Roughly speaking, "coverage provided" is determined by multiplying the years the insurer provided coverage by the coverage limits of the policies. ${ }^{98}$ The court reasoned that insurers who provided more coverage, that is, higher limits or lower deductibles,

\footnotetext{
* See text accompanying notes 79-81. The J.H. France court vaguely suggested, without any discussion, that the policies' "other insurance" clauses could be used to apportion liability. J.H. France, 626 A2d at 509. For a discussion of why these clauses are not applicable to progressive injury allocation, see Section III.D.

${ }^{\approx}$ See text accompanying notes $82-84$.

${ }^{*}$ See text accompanying notes $85-89$.

97138 NJ 437, 650 A2d 974 (1994).

${ }^{2}$ A series of recent opinions in California state court offers a comparison of the Owens-Illinois approach with other approaches. Compare Armstrong World Industries, Inc v Aetna Casualty \& Surety Co, 45 Cal App 4th 1, 52 Cal Rptr 2d 690, 705-11 (1996) (imposing joint and several liability, including during periods of self-insurance, and encouraging contribution based on years of coverage multiplied by policy limits), with Imerica Group, Inc v Liberty Mutual Co, 47 Cal App 4th 699, 50 Cal Rptr 2d 583, 608-11, review granted, $54 \mathrm{Cal}$ Rptr 2d 41 (1996) (using fact-based allocation to allocate defense costs and requiring insurer to pay for costs defending claims involving damage that occurred during uninsured periods). The Imerica court also held that the insured should be responsible for defense costs incurred defending claims involving damage that occurred during uninsured periods. Id at 608-09. See also Stonewall Insurance Co $v$ City of Palos Verdes Estates, 46 Cal App 4th 1810, 54 Cal Rptr 2d 176, 206 (Cal Ct App 1996) (adopting time-on-the-risk as the "fairest" method).
} 
assumed more of the risk of liability than insurers who provided less coverage. The court then held that each insurer would be liable for that portion of the liability corresponding to the ratio of the total coverage provided by that insurer to the total coverage provided by all the triggered policies.

A simplified example will help explain this method. ${ }^{99}$ Assume that XYZ's employees are exposed to asbestos for the nine years they work in XYZ's building. At the end of the nine years, the employees develop asbestosis, but it is impossible to determine when damage to the employees' lungs reached the point of diagnosable injury. Unable to identify the point of injury, the court applies a continuous trigger, triggering all insurance policies in effect from years one through nine. Further assume that in years one through three, insurer A provided coverage with a policy limit of $\$ 2$ million per year. In years four through six, insurer $B$ covered $X Y Z$ with a policy with limits of $\$ 3$ million per year, and in years seven through nine insurer $C$ provided coverage with policy limits of $\$ 4$ million per year. Under the OwensIllinois method, the total coverage provided by the triggered policies equals $\$ 27$ million $(2+2+2+3+3+3+4+4+4=27)$. Insurer $A$ provided coverage for three years with a limit of $\$ 2$ million per year, so A would be liable for 6/27 of the total liability (3 years $* \$ 2$ million per year). Insurer $B$ would be liable for 9/27 of the total liability (3 years $* \$ 3$ million per year), and $\mathrm{C}$ would be liable for $12 / 27$ (3 years $* \$ 4$ million per year). ${ }^{100}$

The Owens-Illinois court also held that a company that did not have insurance for a period during the injury must share in the loss as if it were an insurer. This holding requires a determination of how much risk the self-insurer assumed during that time, that is, how much coverage the self-insurer "provided." The court stated that a special master would develop the actual allo-

\footnotetext{
The following example was adapted from Owens-Illinois, 650 A2d at 994.

${ }^{10}$ The court recognized that deductibles, coinsurance, excess insurance, and other risk-sharing techniques would complicate the allocation formula. Id. "Coinsurance" refers to an insurance risk-sharing technique by which the insurer and the insured divide the liability for each dollar of loss. For example, if XYZ's insurance policy had a coinsurance level of 20 percent, XYZ would pay $\$ 20$ of a $\$ 100$ liability; the insurer would pay $\$ 80$. See generally Mark S. Rhodes, Couch on Insurance § 62:123-25 at 598-99 (Law Co-op 2d ed 1983 \& Supp 1996). "Excess insurance" refers to the practice of buying liability insurance in layers. For example, an insured may purchase from insurer A coverage for any liability less than $\$ 1$ million per occurrence. It then purchases from $B$ a policy providing coverage for liability in excess of $\$ 1$ million and less than $\$ 10$ million per occurrence. The policy purchased from B is "excess" insurance. See generally Abraham, Environmental Liability Insurance Law at 223-33 (cited in note 5).
} 
cation formula on a case-by-case basis, using the basic framework provided above. ${ }^{101}$

Because it actually allocates liability among the various triggered insurance policies and periods of self-insurance, the Owens-Illinois method is superior to the Keene and stacking methods. However, this method is not without its drawbacks. First, it tends to maximize coverage in individual cases and disproportionately assign liability to generous policies, disproportionately increasing their price, thus making them more difficult to purchase.

Furthermore, it increases transaction costs by requiring a special master to apply the deceptively simple formula on a caseby-case basis. The special master must examine periods of selfinsurance and estimate how much coverage was "purchased" during those periods, allocating liability to those periods accordingly. Several factors complicate the special master's calculation. The policies triggered in a progressive injury case will not be identical. Deductible and coinsurance levels will vary, as will policy limits. Moreover, different policy periods may or may not have excess insurance coverage. The Owens-Illinois court anticipated this objection and noted that, compared to the total amounts involved, the expense of hiring a special master is relatively small. ${ }^{102}$ The court failed, however, to guide the special master through complications such as deductibles and excess insurance.

With the special master's wide discretion under the OwensIllinois method, outcomes will likely be less predictable. Since allocation is to be determined on a case-by-case basis, parties will not know how the special master in a particular case will handle deductibles, coinsurance, self-insurance, excess insurance, and other variables when determining the liability of each insurer. ${ }^{103}$

\footnotetext{
${ }^{101}$ Owens-Illinois, 650 A2d at 994.

${ }^{102}$ Id at 995 . The court cited to John H. Gross, Strategic Considerations in Coverage Litigation, in Barry R. Ostrager and Thomas R. Newman, eds, 11th Annual Insurance, Excess, and Reinsurance Coverage Disputes 7 (PLI-Litigation Course Handbook Series No. H-494) (1993), which provides a case history of the use of a special master to streamline a non-allocation-related litigation process.

${ }^{10}$ For example, assume that in years one through three XYZ purchased insurer A's policy, with a policy limit of $\$ 10$ million and a deductible of $\$ 500,000$. In years four through six, XYZ purchased a policy from insurer B with a $\$ 20$ million limit, but in order to keep its premium down accepted a deductible of $\$ 2$ million. In years seven through nine XYZ decided that self-insurance would be more efficient and purchased from $C$ an excess insurance policy providing coverage only for liability in excess of $\$ 20$ million. In year fifteen, XYZ discovers that it will be liable for pollution damage caused by an occurrence that triggered all three policies.

Consider three scenarios. First, XYZ is liable for $\$ 1.5$ million. Liability of $\$ 1.5$ million
} 
This uncertainty does not arise from a mathematical impossibility of developing an allocation formula to handle these variables ${ }^{104}$ but from the courts' opportunity to tinker with results in order to satisfy a desire to maximize insurance coverage in a particular case. ${ }^{105}$ This uncertainty will make it more difficult to set premiums and will encourage wasteful litigation. ${ }^{106}$

Even if courts developed (and, more importantly, consistently used) a standard and predictable method, the OwensIllinois rule has the additional flaw of building "coverage maximization" into the formula. The special master will allocate more liability to policies that provide greater coverage. ${ }^{107}$ Basically, Owens-Illinois treats a progressive injury as a big pie. Because there is no factual way to determine the size of the piece that each insurer should get, Owens-Illinois gives the biggest slices to the policy years that provided the greatest coverage. Years in which the insured purchased less protection and assumed a greater share of potential liabilities (in effect, self-insuring) will be allocated smaller slices. Therefore, insurers pay a greater share of the total damages-maximizing coverage. ${ }^{108}$

Allocating a greater proportion of liability to large insurance policies, while perhaps intuitively appealing, ignores the realities behind the formation of insurance agreements. Holding other factors (such as information and market conditions) constant, the more coverage provided by an insurer, the higher the premium charged. However, the higher premium is charged not because there is a greater chance that a larger injury will occur during

in a single year would cause $A$ to pay $\$ 1$ million. But if this same liability was incurred in a year covered by $\mathrm{B}$, or in a self-insured year, $\mathrm{XYZ}$ would bear the full amount because a $\$ 1.5$ million injury is still the responsibility of the insured. Second, XYZ is liable for $\$ 10$ million. If this liability occurs in year one, A would be required to pay $\$ 9.5$ million. The same injury occurring in year five would require $B$ to pay $\$ 8$ million. If it occurred in year eight, $\mathrm{XYZ}$ would be required to pay the full $\$ 10$ million. Third, $\mathrm{XYZ}$ is liable for $\$ 50$ million. A $\$ 50$ million claim would again require $A$ to pay $\$ 9.5$ million, but if $B$ were liable it would be required to pay $\$ 18$ million. If this injury occurred in year eight, XYZ would have to pay $\$ 20$ million and $\mathrm{C}$ would pay $\$ 30$ million. Thus, for smaller claims, $\mathrm{XYZ}$ gets the most coverage from A. But for larger claims, B's and C's policies provide more coverage.

${ }^{14}$ See, for example, Tung Yin, Comment, Nailing Jello to a Wall: A Uniform Approach for Adjudicating Insurance Coverage Disputes in Products Liability Cases with Delayed Manifestation Injuries and Damages, 83 Cal L Rev 1243, 1276-78 (1995) (proposing formula including provision for deductible amount).

${ }^{105}$ See text accompanying notes 57-58.

${ }^{165}$ See text accompanying notes 7-9 and 46-48.

${ }^{107}$ Owens-Illinois, 650 A2d at 993-94.

${ }^{1 \text { in }}$ See generally Stonewall Insurance, 54 Cal Rptr 2d at 205-07, citing Carriers Insurance Co v American Policyholders' Insurance Co, 404 A2d 216, 221-22 (Me 1979) (stating that allocation based on years of coverage multiplied by policy limits unfairly allocates more liability toward high coverage policies). 
the time period covered by the larger policy. The insurer charges a higher premium because of the increased payout possibility-a $\$ 5$ million policy will only cover half of a $\$ 10$ million injury, while a $\$ 10$ million policy will cover the entire injury. Owens-Illinois ignores this and assumes instead that a greater share of a progressive injury occurs during years with high coverage. ${ }^{109}$ of course, insurers will realize that by providing generous coverage, they invite a greater share of injuries, and will either further increase premiums to reflect their increased liability or will refuse to write policies providing more coverage than policies held by an insured in preceding years.

\section{The "Other Insurance" Clauses Method}

Some courts have suggested using "other insurance" clauses to allocate liability among successive insurers in progressive injury cases. ${ }^{110}$ Courts make this suggestion without discussing how such clauses would allocate liability. "Other insurance" clauses do not provide a solution to the allocation problem because they were not meant to allocate liability among successive insurers, and because policies often have incompatible clauses.

There are three basic types of "other insurance" clauses. ${ }^{111} \mathrm{~A}$ "pro rata" clause provides that the insurer will be liable only for its pro rata share of the loss, usually defined as either an equal share of the loss or as the proportion of the policy's coverage limit to the combined limits of all insurance covering the loss (theoretically similar to the Owens-Illinois method). An "excess" clause states that the policy will only indemnify for amounts over the amount covered by other policies. Finally, an "escape" clause

\footnotetext{
${ }^{109}$ Of course, in some situations, an insured will purchase more coverage because it knows that a change in its activities will increase the likelihood and magnitude of injury. In fact, the Owens-Illinois court stated this as one of its rationales. 650 A2d at 993. In these cases, as in the Uniroyal case, it may be possible for a court to allocate liability based on fact rather than on legal rule. See note 14 . However, increasing coverage does not necessarily mean that an insured's damage-causing activities, and thus the likelihood of injury, have also increased. One might purchase higher policy limits because, for example, juries are returning higher damage awards than they were in previous years, because symptoms of latent illness are beginning to appear, because of the risk of retroactive liability, or because the insured activity is more dangerous than previously thought, even if the level of activity has decreased. See, for example, Eagle-Picher Industries, Inc $v$ Liberty Mutual Insurance Co, 682 F2d 12, 23 (1st Cir 1982) (more insurance coverage purchased despite decrease in damage-causing activities).

${ }^{110}$ See, for example, Keene, $667 \mathrm{~F} 2 \mathrm{~d}$ at 1050; J.H. France Refractories Co $v$ Allstate In-

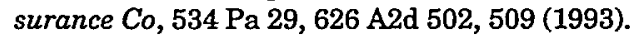

"The following descriptions are taken from Marcy Louise Kahn, The "Other Insurance" Clause, 19 Forum 591, 594-95 (1984).
} 
attempts to eliminate all coverage if any other coverage is available.

Regardless of the clause used, these clauses are not intended as allocation devices between consecutive insurance policies. They do not give insurers rights of contribution against other insurers; instead, they are individual contractual agreements between the insured and each insurer, designed to prevent the insured from recovering multiple times for an injury that occurs at one point of time. ${ }^{12}$ The clauses refer to losses covered by other insurance "on the same basis," that is, by policies concurrently covering the same time period. ${ }^{113}$ Allocation issues arise because progressive injuries do not occur "on the same basis" for each insurance carrier; instead, consecutive policies are triggered because the policies cover different periods of time. ${ }^{114}$

An additional problem arises when the triggered policies have incompatible clauses. For example, policy A may have an excess clause while policy $B$ has a pro rata clause. ${ }^{115}$ In these frequently recurring situations, the courts' responses are characterized by "confusion, inconsistency and the absence of rational guidelines for interpretation."116 Courts often disregard the clauses and simply attempt to allocate liability based on some other method. ${ }^{117}$

The inability of "other insurance" clauses to solve the allocation dilemma demonstrates the difficulty in attempting to solve this problem contractually, rather than judicially or legislatively. While allocation disputes are disputes primarily between insurance companies, an insurance policy is an agreement between an insurer and an insured. The policies do not give insurers contractual rights against other insurers that contracted with the insured at different times. ${ }^{118}$

\footnotetext{
${ }^{112}$ See, for example, Western Agricultural Insurance Co $v$ Industrial Indemnity Insurance Co, 838 P2d 1353, 1357 (Ariz App 1992).

${ }^{13}$ Hickman and DeYoung, $17 \mathrm{~N} \mathrm{Ky} \mathrm{L} \mathrm{Rev} \mathrm{at} 306 \mathrm{n} 45$ (cited in note 8). See also Rhodes, Couch on Insurance $\S 62: 93-96,112$ at 571-76, 588-89 (cited in note 100).

"'See, for example, Owens-Illinois, 650 A2d at 991 (noting that if the triggered policies do not overlap, other insurance clauses are not applicable). But see Barry R. Ostrager and Thomas R. Newman, Handbook on Insurance Coverage Disputes $\$ 9.01$ at 281-82 (Prentice Hall Law \& Bus 3d ed 1990) (citing cases where "other insurance" coverage found for consecutive policies).

${ }^{115}$ See Kahn, 19 Forum at 593 (cited in note 111).

"id Id.

${ }^{117}$ See id at 596-98. See generally Keeton and Widiss, Insurance Law $\$ 3.11(\mathrm{e})$ at 26267 (cited in note 6).

"NThis limitation has not prevented the California Supreme Court from trying to allocate liability based on nonexistent rights. That court recently stated that the allocation of progressive injury liability "requires application of principles of contract law to the express terms and limitations of the various policies of insurance on the risk." Montrose
} 
Of course, the standard language of the CGL form could be changed to select an allocation method. Presumably the insurance industry would select the optimal (time-on-the-risk) method and thus parties would have no incentive to modify the language in individual contracts. This selection would ideally provide the courts with the justification for using a consistent allocation method. Unfortunately, as they have with pollution exclusion clauses, courts may ignore this language to maximize coverage in individual cases. ${ }^{119}$ This possibility reinforces the need for the courts (or the legislatures) to select and consistently apply an allocation method.

\section{THE OPTIMAL ALLOCATION METHOD: TIME-ON-THE-RISK PRORATION}

The time-on-the-risk method, like the "coverage provided" method in Owens-Illinois, allocates liability among triggered policies. However, it uses only the time periods covered by each insurer without considering the coverage limits of the triggered policies. In Insurance Company of North America $v$ Forty-Eight Insulations, Inc, the Sixth Circuit faced a question similar to that faced by the Owens-Illinois court: how to allocate twenty years of asbestos liability among five different insurance companies. ${ }^{120}$ The court prorated the liability, but used a formula much simpler than that employed by the Owens-Illinois court. It allocated liability based on time-on-the-risk without regard to the limits of the policy. ${ }^{21}$

Chemical Corp v Admiral Insurance Co, $10 \mathrm{Cal}$ 4th 656, 42 Cal Rptr 2d 324, 344 n 19 (1995). However, the court gave no guidance as to how this might be accomplished. Incredibly, to support this proposition, the court then cited Insurance Co of North America $v$ Forty-Eight Insulations, Inc, 633 F2d 1212 (6th Cir 1980), clarified by 657 F2d 814 (6th Cir 1981), and Keene, 667 F2d 1034, cases that use almost identical policy language to reach very different results. Because of this lack of guidance, three California courts that have addressed the allocation issue recently have each used different methods. See note 98.

${ }^{19}$ See text accompanying notes 57-63. See Abraham, 88 Colum L Rev at 960 (cited in note 7) (" $\left[\int\right]$ udicial interpretations of policy language that insurers had regarded as fixed, clear, and limiting have expanded the scope of coverage . . . [and] destabilize[d] the insuring function."). See generally id at 960-72.

${ }^{120} 633$ F2d 1212, 1213-14 (6th Cir 1980), clarified by 657 F2d 814 (6th Cir 1981).

${ }^{121}$ Forty-Eight Insulations, 633 F2d at 1224-25. Other courts using this method include Northern States Power Co $v$ Fidelity and Casualty Co of New York, 523 NW2d 657, 664 (Minn 1994) (en banc); Commercial Union Insurance Co v Sepco Corp, 765 F2d 1543 (11th Cir 1985). 
A. Application of the Time-on-the-Risk Method

The example used to illustrate the Owens-Illinois method illustrates the time-on-the-risk method as well. ${ }^{122}$ Since insurer A covered XYZ for three of the nine years, it is liable for one-third of the total liability. Similarly, insurers B and C, who each covered three years as well, each are liable for one-third of the total liability. The same result would be reached by allocating oneninth of the total liability to each year.

The limits of the policies do not affect how much liability is allocated to each policy, but the limits will affect total payout. For example, if liability totaled $\$ 27$ million, $\$ 3$ million would be allocated to each of the nine years of coverage. Because insurer A only insured XYZ up to a total of $\$ 2$ million per year, XYZ would absorb $\$ 1$ million a year in liability for years one through three. But XYZ would receive full indemnification from the larger policies covering years four through nine.

Similarly, deductibles would not affect the total liability allocated to each year, but would affect the total amount of liability owed by the insurer. For example, if insurer B's policies, with a limit of $\$ 3$ million per year, had a deductible of $\$ 100,000$ per year, B would indemnify XYZ at $\$ 2.9$ million per year. (XYZ would pay the first $\$ 100,000$ of liability per year, after which B would cover the rest up to the limit of $\$ 3$ million, a limit not reached in this example.) $)^{123}$

Under the time-on-the-risk allocation method, self-insured periods should be treated in the same way as insured periods, with the insured paying 100 percent of the allocated liability for the years in which it self-insured. ${ }^{124}$ For example, if XYZ decided to self-insure during years seven through nine, it would absorb the entire $\$ 3$ million of liability per year, for a total of $\$ 9$ million of liability.

\section{B. Defense of Time-on-the-Risk}

The time-on-the-risk method should be adopted by courts because its inherent simplicity promotes predictability, reduces incentives to litigate, and ultimately reduces premium rates.

Courts can easily administer the time-on-the-risk method. Once a court determines the scope of the progressive injury, that is, the total damage and the period of time from exposure to

\footnotetext{
${ }^{12}$ See text accompanying notes $99-100$.

${ }^{12}$ This result is the same as would occur if an instantaneous accident caused a oneyear liability of $\$ 3$ million.

${ }^{12}$ Forty-Eight Insulations, $633 \mathrm{~F} 2 \mathrm{~d}$ at 1224-25.
} 
manifestation, it can readily allocate the damages among the triggered policies. The court divides the total damages by the number of triggered years and simply allocates to each year the result. If, for example, a certain policy spans three years out of a total of ten triggered years, then thirty percent of the damages will be allocated to that policy.

Unlike the Owens-Illinois method, the effects of deductibles, excess insurance, and self-insurance are easy to calculate by pretending that the policy's share of damages was the damage that actually occurred during that policy period. The deductible, if any, will apply against the allocated damages, because the damages arise from a single occurrence. If damages exceed the policy's limits, then either the insured or the insured's excess insurance policy for that period must bear the cost of the excess damages. ${ }^{125}$ During periods of self-insurance, the insured bears the cost of all allocated damages.

The time-on-the-risk method has intuitive, commonsense appeal, as noted by Judge Wald in her partial concurrence in Keene:

It seems to me logical and fair . . . to distribute the ultimate financial responsibility on a pro rata basis among the various insurance companies on line during the risk period, and to include Keene as a self-insurer for the years when it failed to take out any insurance. ${ }^{126}$

The simplicity of the time-on-the-risk method removes many of the incentives to litigate the allocation of damages. Since the parties will know in advance how the court will allocate liability, there is much less of the uncertainty that encourages wasteful litigation. ${ }^{127}$ As discussed, litigation costs in progressive injury cases are almost as large as actual damage costs. ${ }^{128}$ While there will still be many issues to litigate, such as which policies are triggered and total damages, reducing the amount of allocation litigation should substantially decrease the costs of insurance.

In addition to decreasing the amount of litigation, this method provides a way for insurance companies to estimate more accurately total expected liability; as a result, premiums should decline. Premiums reflect the uncertainty that exists in the insurance market and the possibility that courts will use a coverage maximization rule to allocate coverage. Uncertainty about

\footnotetext{
${ }^{125}$ Hickman and DeYoung, $17 \mathrm{~N}$ Ky L Rev at $308 \mathrm{n} 51$ (cited in note 8).

${ }^{125} 667$ F2d at 1058 (Wald concurring) (advocating time-on-the-risk approach).

${ }^{17}$ See Posner, Economic Analysis of Law at 555-59 (cited in note 8).

${ }^{1}$ See text accompanying notes 10-12.
} 
which allocation method will be used and how that method will be applied increases the costs of insurance. ${ }^{129}$ Consistent use of the time-on-the-risk method will eliminate the concern about uncertainty. Because this method, unlike the Owens-Illinois method, does not rely on a case-by-case determination of how much coverage was purchased, it also obviates the concern about inconsistent application. ${ }^{130}$

Critics of the time-on-the-risk method may object that it is unfair to allocate the same amount of damages to low- and highcoverage policies, presumably because the insured pays more for the high-coverage policies. ${ }^{131}$ However, such allocation is entirely fair. Policies will indemnify the insured only up to their policy limits; if allocated damages are higher than a policy's limit, the insurer will not be liable for the excess. As total damages increase, high-coverage policies will pay more than low-coverage policies, because the low-coverage policies' limits will be reached earlier. And in some low-damage cases, policies that provide much less total coverage will provide greater indemnification because of their lower deductible levels. Thus, policies with higher limits will on average, but not always, pay more than policies with low limits.

Critics might also object that the time-on-the-risk method assumes that actual damages occurred evenly within each triggered policy period. While this objection is almost surely correct, other allocation methods share this defect. Progressive injuries by definition do not occur within a single policy period (Keene), nor do they magically gravitate toward periods with more coverage (Owens-Illinois). The time-on-the-risk method does not pre-

\footnotetext{
${ }^{229}$ See text accompanying notes 7-9 and 46-48.

${ }^{139}$ The policies supporting the allocation of indemnity by the time-on-the-risk method also support using this method to apportion the insurer's duty to defend an insured under the standard CGL policy language. A liability insurer owes a duty to defend its insured against third-party actions that seek damages potentially covered by the insured's policy. As with indemnity, insurers have tried to avoid the costs of the duty to defend, and courts have allocated this duty inconsistently. Compare Keene, $667 \mathrm{~F} 2 \mathrm{~d}$ at 1050-51 \& n 37 (imposing joint and several liability but allowing later allocation among insurers), with Forty-Eight Insulations, $633 \mathrm{~F} 2 \mathrm{~d}$ at 1225 (allocating defense costs using the time-on-therisk method), and Owens-Illinois, 650 A2d at 994-95 (allocating defense costs based on the proportion of total coverage provided). As with allocating indemnity, the time-on-the-risk method reduces uncertainty and the incentives to litigate. In addition, using the same method to allocate indemnity and defense ensures that insurance companies bear the same proportion of both costs and reduces the risk that they will engage in strategic behavior by, for example, settling a claim quickly in order to minimize defense costs (which it may bear itself) at the expense of negotiating a better settlement (the benefits of which may be allocated among several insurers). See Sykes, 72 Tex L Rev at 1346 (cited in note 84).

${ }^{131}$ See, for example, Toxic Waste Litigation, 99 Harv L Rev at 1583-84 (cited in note 7).
} 
tend to base allocation on the "facts" because these facts are unavailable. Because facts cannot be used to allocate the damages, other considerations must prevail.

In addition, the method's simplicity may lead to some strained applications. Consider the treatment of deductibles. Many policies have a "per occurrence" deductible. However, by definition, a progressive injury is caused by one occurrence. This leads to the possibility that the damages caused by a single occurrence may force an insured to meet several "per occurrence" deductibles.

One might suggest using a formula to determine the "average size" of the deductible purchased and then proportionally allocate this deductible to the various triggered policies. ${ }^{132}$ However, such a complication erodes the superiority of the timeon-the-risk method, a superiority grounded in simplicity. A simpler method would force the insured to meet the deductible for each policy.

Making the insured meet each deductible would avoid wasteful litigation among insurers and with the insured over the proper allocation formula. ${ }^{133} \mathrm{~A}$ deductible only allocates a loss between an insured and an insurer; it does not make the loss disappear. Any litigation over deductibles concerns only distribution; the ideal rule would eliminate this litigation. If fewer losses are allocated to insurers because insureds must meet multiple deductibles, premiums should shrink to reflect this change. Insureds who do not wish to run the risk of being forced to meet several deductibles can pay extra for policies with minimal de-

\footnotetext{
${ }^{152}$ For example, assume XYZ had three different policies within a three-year span. Policy A had no deductible. Policy B had a $\$ 3,000$ deductible. Policy C had a $\$ 6,000$ deductible. The average deductible for the three years would be $\$ 3,000$ ( $\$ 9,000$ in total deductibles divided by three years). XYZ would be forced to pay $\$ 3,000$ out-of-pocket before the remaining damages were allocated among the insurance companies. Complications arise, however. Because $\mathrm{A}$ had no deductible, why should $\mathrm{A}$ receive the benefit of the other policies' deductibles, especially since A charged a higher premium for the lack of deductible? Another approach would allow no part of the deductible to be allocated to $A$; it would have to pay claims starting with the first dollar of damages. Of the remaining two policies, policy $\mathrm{B}$ provided one-third of the total deductible and $\mathrm{C}$ provided two-thirds. Therefore, $B$ would be allocated $\$ 1,000$ of the deductible. Of the damages allocated to the $B$ policy period (one-third the total damages), $\mathrm{XYZ}$ would need to pay $\$ 1,000$ before $\mathrm{B}$ provided coverage. C's policy period would be treated similarly. This tortured, confusing, and manipulable result further demonstrates the need for an easily administrable and predictable approach.

${ }^{123}$ However, the insurers would more readily settle because the amounts involved would be smaller. See Posner, Economic Analysis of Law at 555-59 (cited in note 8) (demonstrating that decreasing the stakes of litigation increases the likelihood of settlement).
} 
ductibles. The certainty gained will lower total costs more effectively than any alternative.

A close examination suggests that the simple method has logical as well as practical appeal. One reason to define progressive injuries as caused by a single occurrence is the lack of facts that would allow parties to determine exactly when and how the injury occurred. For example, years of pollution at a site may be treated as caused by one occurrence. However, this pollution may have been caused by two distinct operations-the use of chemicals in the company's operations and the on-site storage of waste products. If the court could ascertain the amount of cleanup costs attributable to each activity, each activity could be treated as a separate occurrence. ${ }^{134}$ Policies would be triggered and damage allocated for each occurrence; the insured would be forced to meet two "per occurrence" deductibles, even if it were insured by one policy during the whole period. Because costs cannot be allocated to the activities causing the damages, however, the entire operation is considered one occurrence, and the insured need only meet one deductible. Making the insured meet a deductible for each policy tracks somewhat what could occur if more information were available.

\section{CONCLUSION}

Courts should choose a method for allocating progressive injury liability that minimizes the present and future costs of progressive injuries. The time-on-the-risk method limits the cost of injuries that have already occurred by minimizing litigation costs-costs that are often larger than the cost of the original injury.

The time-on-the-risk method also reduces future progressive injury damages. The method encourages companies to insure. The monitoring and internalization functions of insurance encourage companies to minimize future progressive injury costs. As a result, future progressive injury damages decline.

Insurance companies also bear the duty to defend the insured. These defense costs should be allocated using time-on-therisk, both to minimize litigation costs and to minimize the costs of strategic negotiation.

\footnotetext{
${ }^{134}$ See, for example, Hickman and DeYoung, $17 \mathrm{~N} \mathrm{Ky} \mathrm{L} \mathrm{Rev} \mathrm{at} 297$ (cited in note 8) (A progressive injury can often be seen either as the result of one continuous act or of multiple acts.).
} 
